\title{
Antecedents and Consequences of User Satisfaction with an e-Learning Portal
}

\author{
Christy M.K. Cheung \\ Department of Finance \\ and Decision Sciences \\ Hong Kong Baptist University
}

\author{
Matthew K.O. Lee \\ Department of Information Systems \\ City University of Hong Kong
}

\begin{abstract}
The study is one of the very few attempts to investigate antecedents and consequences of user satisfaction with an e-learning portal. Building on prior literature, the research model postulates a positive link between overall satisfaction and intention to continue to use an e-learning portal. Data collected from 504 undergraduate students are examined through the Structural Equation Modeling approach with Partial Least Squares (PLS). Empirical findings demonstrate that our research model provides a relatively high explanatory power. Moreover, all associated hypotheses are found to have statistically significance. The implications of this study are noteworthy for both researchers and practitioners.
\end{abstract}

\section{Introduction}

An e-learning portal is typically composed of a web-based environment for the interactive delivery of multimedia course material. Individual users are able to browse hyper-linked multimedia course material on the web and to track their progress through taking an online quiz anytime, anywhere and at their own place. As the use of the Internet becomes further widespread and global, e-learning portals are becoming increasingly important as vehicles for continuous learning in both educational institutions and the corporate training world.

The range of research related to e-learning is unexpectedly broad [1]. Piccoli et al [2] proposed a research framework for the assessment of learning outcomes associated with web-based virtual learning environments. Ong et al. [3] investigated the adoption of e-learning systems in high-tech firms. Limayem and Cheung [4] studied how habit affects students' continuance intention in e-learning systems. Riva [5] focused on creating and maintaining virtual learning communities in an online learning environment. However, there is a lack of understanding about user reactions to such a learning portal.

Satisfaction is one of the most important user reactions. There are numerous studies in the literature establishing the link between user satisfaction and crucial outcome variables [6]. It is believed that the success of an e-learning portal depends on whether users are satisfied with and are willing to continue to use that particular e-learning system. The purpose of this study is to examine the nature of satisfaction in the context of an e-learning portal, and to identify the antecedents and consequences of satisfaction with an e-learning portal.

The rest of the paper is organized as follows. The next section provides a review of the relevant literature on user satisfaction in the IS field. The third section presents the research model and hypotheses, and the fourth section describes a survey study of users of an e-learning portal (Blackboard) to empirically test the research model. The fifth section reports the statistical results, and the paper is concluded by discussing its implications for both research and practice.

\section{Literature Review on User Satisfaction}

User satisfaction has been extensively studied in the field of IS and it has been widely adopted as an important measure of the success or effectiveness of information systems [7]. Early IS research tended to focus primarily on the operationalization of the satisfaction construct and ignored the theoretical bases [8]. In response to the call for a rigorous theoretical support in the study of user satisfaction, there is an increasing amount of user satisfaction studies grounded with theories. Expectation disconfirmation theory [9] is one of the most widely used theoretical frameworks in user satisfaction research [10], [6]. Based on the expectation confirmation framework, user satisfaction is postulated as a function of the degree to which expectations match, exceed, or fall short of performance.

In the end user computing (EUC) environment, users consume information through direct interaction with application systems. From this vantage point, the phenomenon of end user computing is characterized by both information consumption and direct user interaction [11]. Information quality and system quality, representing the semantic level and technical level respectively, are postulated as two key antecedents of user satisfaction [12]. The quality of information is typically evaluated by measuring 
information attributes. For example, Doll and Torkzadeh [11] developed a measure that includes content, accuracy, format and timeliness of system output. System quality is mostly represented in prior research by ease of use [13]. Recently, the proliferation of electronic commerce has further provoked IS researchers' interest in the study of user satisfaction in the online environment [14], [15], [16].

To a certain extent, the use of an e-learning portal can be regarded as a computer application involving interactions with a computer environment. Elearning portal usage experience heavily relies upon the information published, as well as the quality of the system. McKinney et al. [15] specified web satisfaction as being comprised of both information satisfaction and system satisfaction. These two satisfactions are in turn affected by a number of attributes of information quality and system quality respectively. They further built on the expectation disconfirmation theory and proposed that information satisfaction and system satisfaction are determined by information quality disconfirmation and system quality disconfirmation respectively. These disconfirmations are based on the evaluations of the expectation and perceived performance of the quality constructs. This web user satisfaction model has provided a solid foundation for other studies regarding satisfaction in ERP use [17], and continuance intention in virtual communities [18].

\section{Research Model and Hypotheses}

Figure 1 (see below) depicts the research model of this study. It is an extended model of ExpectationDisconfirmation Effects on Web-Customer Satisfaction [15]. McKinney et al. [15] postulated that web-customer satisfaction is predicted by webinformation quality satisfaction and web-system quality satisfaction. Web-information quality satisfaction is influenced by information quality disconfirmation, whilst Web-system quality satisfaction is predicted by system quality disconfirmation. Incorporating expectationdisconfirmation theory, McKinney et al. [15] further posited that information quality satisfaction is affected by information quality expectation and information quality performance, whereas system quality satisfaction is affected by system quality expectation and system quality performance.

\subsection{Continuance Intention and User Satisfaction}

In this study, McKinney's [15] model was extended by postulating a positive link between overall satisfaction and intention to continue to use. Intention to continue to use has been receiving enormous attention in recent years. Bhattacherjee
[10] empirically demonstrated a positive relationship between satisfaction and intention to continue to use. In the context of e-learning portals, it is believed that satisfaction is also a primary driver to the intention to continue to use the system.

H1: Overall Satisfaction with an e-learning portal positively affects Intention to Continue to Use.

\subsection{Information Satisfaction and System Satisfaction}

Satisfaction is an affective state that is the emotional reaction to a product or service experience [19]. End-user computing (EUC) satisfaction refers to the satisfaction of an end-user's (who is typically not a computing professional) with a computer application when directly interacting with it and consuming its information output. According to Doll and Torkzadeh [11], the performance of end-user information systems includes both information quality and interface/system quality. McKinney et al. [15] posited that web consumer satisfaction has two distinctive information and system satisfaction with the website system performance in delivering information. An e-learning portal is a web-based application that students interact with and consume the information output. Hence, overall satisfaction is affected by both information satisfaction and system satisfaction.

H2: Information Satisfaction with an e-learning portal positively affects Overall Satisfaction with an e-learning portal.

H3: System Satisfaction with an e-learning portal positively affects Overall Satisfaction with an elearning portal.

\subsection{Information Quality}

Information quality has been considered important because providing high quality information to users has been consistently viewed as a key determinant of user acceptance [20]. The quality of information is typically evaluated by measuring information attributes. For example, Doll and Torkzadeh [11] developed a measure that included content, accuracy, relevancy, format, and timeliness of system output. DeLone and McLean [7] extended the dimensions of information quality to fit the context of e-commerce. In McKinney et al.'s [15] web satisfaction model, understandability, reliability, and usefulness of information are the three key dimensions related to information quality. The definition and supporting references of the three key attributes of information quality are summarized in Table 1.

Based on expectation disconfirmation theory, the fulfillment of user perceptions of the three key attributes of information quality will lead to higher information satisfaction. 


\section{Figure 1. Research model}

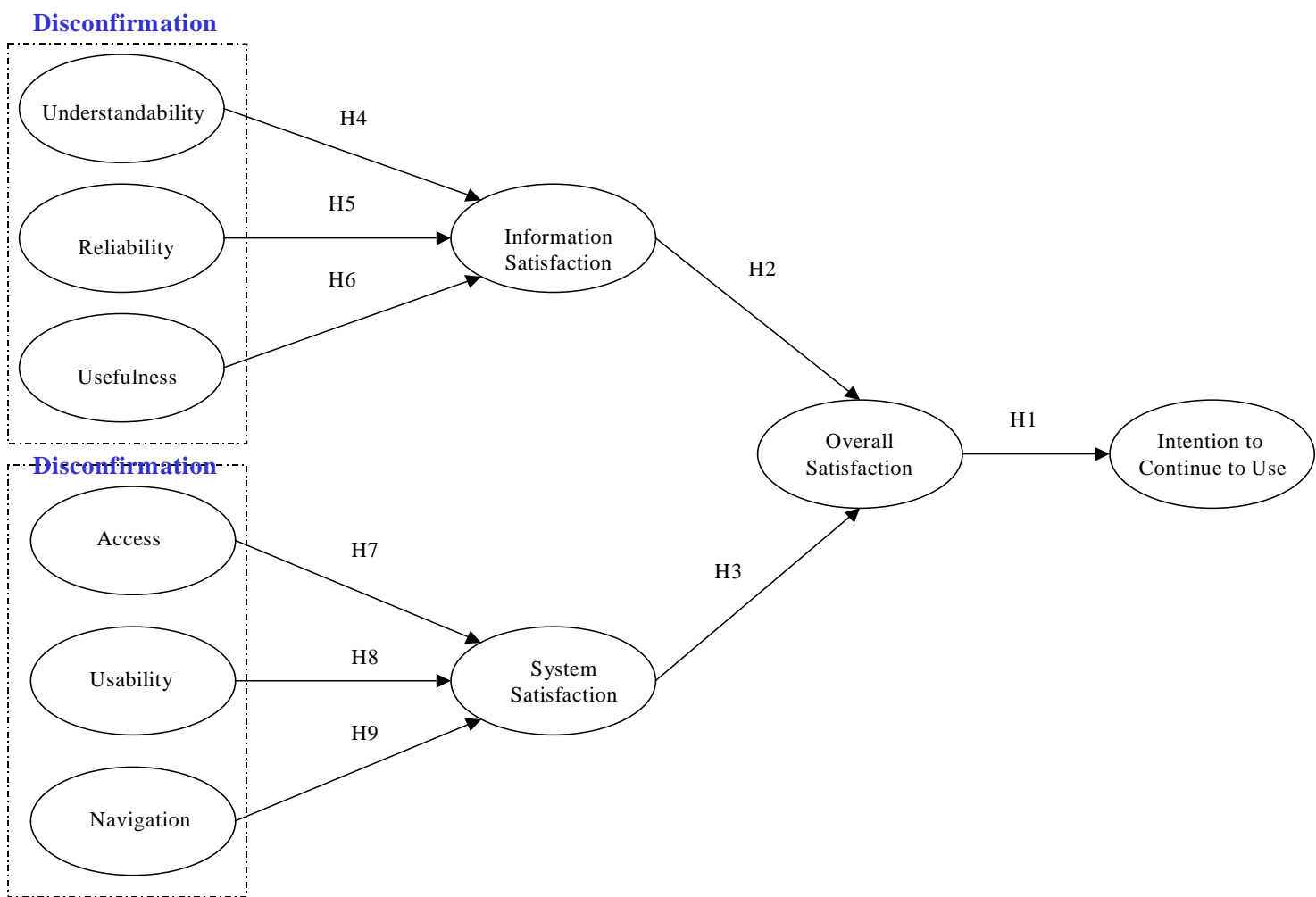

H4: Disconfirmation of understandability of an $e$ learning portal positively affects information satisfaction with an e-learning portal.

H5: Disconfirmation of reliability of an e-learning portal positively affects information satisfaction with an e-learning portal.

H6: Disconfirmation of usefulness of an e-learning portal positively affects information satisfaction with an e-learning portal.

\subsection{System Quality}

System quality is a measure of the information processing system itself, and focuses on the outcome of the interaction between the user and the system. In the context of Internet shopping, system quality is largely characterized by the interaction between consumers and the website (e.g. Information searching, downloading, and performing ecommerce transactions) [21], [22]. In the DeLone and McLean Updated IS Success Model [7], system quality is a key attribute associated with user satisfaction in the e-commerce context, and the model suggests that usability, availability, reliability, adaptability, and response time (e.g. download time) are examples of qualities that are valued by users.
McKinney et al. [15] empirically determined three dimensions of system quality for web customer satisfaction, including access, usability, and navigation. Their definitions and supporting references are summarized in Table 1.

Similar to the previous argument, the fulfillment of user perceptions of the three key attributes of system quality will lead to higher system satisfaction. H7: Disconfirmation of access of an e-learning portal positively affects system satisfaction with an elearning portal.

H8: Disconfirmation of usability of an e-learning portal positively affects system satisfaction with an $e$ learning portal.

H9: Disconfirmation of navigation of an e-learning portal positively affects system satisfaction with an $e$ learning portal.

\section{Research Method}

The learning innovation in question is known as "Blackboard", which is a learning portal for the students in a campus-based university. The elearning portal contains lecture and tutorial materials, course announcements, and all relevant documents. The portal also contains communication facilities 
Table 1. Description of the six key attributes (Complied from McKinney et al. 2002)

\begin{tabular}{|l|l|l|}
\hline \multicolumn{1}{|c|}{ Attribute } & \multicolumn{1}{|c|}{ Definition } & \multicolumn{1}{c|}{ Manifest Variables } \\
\hline Understandability & $\begin{array}{l}\text { Concerned with such issues as clearness and } \\
\text { goodness of the information }\end{array}$ & $\begin{array}{l}\text { - Clear in meaning } \\
\text { - Easy to understanding } \\
\text { - Easy to read }\end{array}$ \\
\hline Reliability & $\begin{array}{l}\text { Concerned with the degree of accuracy, } \\
\text { dependability, and consistency of the } \\
\text { information }\end{array}$ & $\begin{array}{l}\text { - Trustworthy } \\
\text { - Accurate } \\
\text { - Credible }\end{array}$ \\
\hline Usefulness & $\begin{array}{l}\text { Users' assessment of the likelihood that the } \\
\text { information will enhance their decision }\end{array}$ & $\begin{array}{l}\text { - Informative } \\
\text { - Valuable }\end{array}$ \\
\hline Access & $\begin{array}{l}\text { Refers to the speed of access and availability of } \\
\text { the web site at all times }\end{array}$ & $\begin{array}{l}\text { - Responsive } \\
\text { - Quick loads }\end{array}$ \\
\hline Usability & $\begin{array}{l}\text { Concerned with the extent to which the web site } \\
\text { is visually appealing, consistent, fun and easy to } \\
\text { use }\end{array}$ & $\begin{array}{l}\text { - Simple layout } \\
\text { - Easy to use } \\
\text { - Well organized }\end{array}$ \\
\hline Navigation & Evaluates the links to needed information & $\begin{array}{l}\text { - Easy to go back and forth } \\
\text { - A few clicks }\end{array}$ \\
\hline
\end{tabular}

(e.g. discussion forums, group pages, and chat rooms) for students to exchange ideas and opinions, and to contribute feedback on the teaching materials. The portal was introduced to the first-year undergraduate students at the beginning of the semester. An online survey was then administrated to these students after their usage for six-week time. A total of 504 usable questionnaires were collected. Participation in this study was voluntary. To encourage participation, incentives of three USB memory drives were offered as lucky draw prizes to respondents. Among the respondents, $45.2 \%$ are male and $54.8 \%$ are female.

The questionnaire covered all the measures of the constructs in our research model. The measures of this research were borrowed from McKinney et al. [15] with modifications to fit the specific context of an e-learning portal. Table 2 shows the sample items of this study.

\section{Data Analysis and Results}

Structural equation modeling (SEM) is a secondgeneration multivariate technique that is important in instrument validation, model building, and model testing. According to Hair et al. [23] SEM is characterized by its ability to estimate multiple and interrelated dependent relationships, and to measure unobserved concepts in these relationships uncontaminated by measurement error. In this study, both psychometric properties and model testing were examined using the SEM approach with Partial Least Squares (PLS) as a basic statistical analytical tool for data analysis.

\subsection{Instrument Validation}

In this study, the instrument validity is evaluated in terms of reliability and construct validity. For reliability of the scale, composite reliability and average variance extracted are used to assess as suggested by Chin [24] and Fornell and Larcker [25]. Table 2 shows that all constructs exhibit a high degree of internal consistency with composite reliability and average variance extracted of the constructs larger than 0.700 . For checking discriminant validity, the average variance extracted for a particular construct is compared to its correlations with the other constructs [25]. Table 3 illustrates that the square root of average variance extracted is greater than the correlations between the constructs and all other constructs. The results suggest an adequate convergent and discriminant validity of the measurement.

Table 3. Correlation matrix of the constructs (Note: Diagonal elements are the square root of average variance extracted)

\begin{tabular}{|l|l|r|r|r|r|r|r|r|r|r|r|}
\hline & & $\mathbf{1}$ & $\mathbf{2}$ & $\mathbf{3}$ & $\mathbf{4}$ & $\mathbf{5}$ & $\mathbf{6}$ & $\mathbf{7}$ & $\mathbf{8}$ & $\mathbf{9}$ & $\mathbf{1 0}$ \\
\hline $\mathbf{1}$ & Understandability & $\mathbf{0 . 9 0 2}$ & & & & & & & & & \\
\hline $\mathbf{2}$ & Reliability & 0.669 & $\mathbf{0 . 8 8 5}$ & & & & & & & & \\
\hline $\mathbf{3}$ & Usefulness & 0.651 & 0.680 & $\mathbf{0 . 9 1 0}$ & & & & & & & \\
\hline $\mathbf{4}$ & Access & 0.631 & 0.623 & 0.694 & $\mathbf{0 . 8 5 2}$ & & & & & & \\
\hline $\mathbf{5}$ & Usability & 0.604 & 0.642 & 0.629 & 0.687 & $\mathbf{0 . 8 9 2}$ & & & & & \\
\hline $\mathbf{6}$ & Navigation & 0.647 & 0.615 & 0.642 & 0.673 & 0.625 & $\mathbf{0 . 8 9 8}$ & & & & \\
\hline $\mathbf{7}$ & Information Satisfaction & 0.588 & 0.572 & 0.584 & 0.601 & 0.604 & 0.592 & $\mathbf{0 . 9 0 2}$ & & & \\
\hline $\mathbf{8}$ & System Satisfaction & 0.577 & 0.554 & 0.598 & 0.596 & 0.615 & 0.614 & 0.677 & $\mathbf{0 . 9 1 1}$ & & \\
\hline $\mathbf{9}$ & Overall Satisfaction & 0.579 & 0.556 & 0.563 & 0.594 & 0.612 & 0.599 & 0.849 & 0.873 & $\mathbf{0 . 9 2 2}$ & \\
\hline $\mathbf{1 0}$ & Intention to Continue to Use & 0.472 & 0.462 & 0.480 & 0.520 & 0.548 & 0.496 & 0.633 & 0.651 & 0.642 & $\mathbf{0 . 8 9 3}$ \\
\hline
\end{tabular}


Table 2. Sample item and psychometric properties of measures

\begin{tabular}{|c|c|c|c|c|}
\hline & & $\begin{array}{l}\text { Composite } \\
\text { Reliability }\end{array}$ & \begin{tabular}{|l|} 
Average \\
Variance \\
Extracted
\end{tabular} & $\begin{array}{l}\text { Item } \\
\text { Loading }\end{array}$ \\
\hline \multicolumn{2}{|c|}{ Access (Much lower than you thought to Much higher than you thought) } & 0.888 & 0.726 & \\
\hline & The System of Blackboard in terms of: & & & \\
\hline DACC1 & a. $\quad$ responsive to your request is & & & 0.807 \\
\hline DACC2 & quickly loading all the text and graphic is & & & 0.862 \\
\hline DACC3 & c. $\quad$ providing good access for you to use is & & & 0.885 \\
\hline \multicolumn{2}{|c|}{ Usability (Much lower than you thought to Much higher than you thought) } & 0.940 & 0.796 & \\
\hline & The System of Blackboard in terms of: & & & \\
\hline DUSA1 & a. $\quad$ having a simple layout for its contents is & & & 0.869 \\
\hline DUSA2 & easy to use is & & & 0.907 \\
\hline DUSA3 & well organized is & & & 0.901 \\
\hline DUSA4 & d. $\quad$ user-friendly is & & & 0.890 \\
\hline \multicolumn{2}{|c|}{ Navigation (Much lower than you thought to Much higher than you thought) } & 0.926 & 0.806 & \\
\hline & The System of Blackboard in terms of: & & & \\
\hline DNAV1 & a. $\quad$ easy to go back and forth between pages is & & & 0.898 \\
\hline \begin{tabular}{|l|} 
DNAV2 \\
\end{tabular} & providing a few clicks to locate information is & & & 0.898 \\
\hline DNAV3 & c. easy to navigate is & & & 0.897 \\
\hline \multicolumn{2}{|c|}{ Information Satisfaction } & 0.946 & 0.814 & \\
\hline INSAT1 & $\begin{array}{l}\text { a. [Semantic differential scale from } 1=\text { very dissatisfied to } 7=\text { Very } \\
\text { satisfied] }\end{array}$ & & & 0.906 \\
\hline INSAT2 & $\begin{array}{l}\text { b. [Semantic differential scale from } 1=\text { very displeased to } 7=\text { Very } \\
\text { pleased] }\end{array}$ & & & 0.915 \\
\hline INSAT3 & c. [Semantic differential scale from $1=$ frustrated to $7=$ Contented] & & & 0.888 \\
\hline INSAT4 & d. [Semantic differential scale from $1=$ disappointed to $7=$ Delighted] & & & 0.901 \\
\hline \multicolumn{2}{|c|}{ System Satisfaction } & 0.951 & 0.829 & \\
\hline SYSSAT1 & $\begin{array}{l}\text { a. [Semantic differential scale from } 1=\text { very dissatisfied to } 7=\text { Very } \\
\text { satisfied] }\end{array}$ & & & 0.910 \\
\hline SYSSAT2 & $\begin{array}{l}\text { b. [Semantic differential scale from } 1=\text { very displeased to } 7=\text { Very } \\
\text { pleased] }\end{array}$ & & & 0.918 \\
\hline SYSSAT3 & c. $[$ Semantic differential scale from $1=$ frustrated to $7=$ Contented $]$ & & & 0.911 \\
\hline SYSSAT4 & d. [Semantic differential scale from $1=$ disappointed to $7=$ Delighted] & & & 0.903 \\
\hline \multicolumn{2}{|c|}{ Overall Satisfaction } & 0.958 & 0.851 & \\
\hline SAT1 & $\begin{array}{l}\text { a. [Semantic differential scale from } 1=\text { very dissatisfied to } 7=\text { Very } \\
\text { satisfied] }\end{array}$ & & & 0.912 \\
\hline SAT2 & $\begin{array}{l}\text { b. [Semantic differential scale from } 1=\text { very displeased to } 7=\text { Very } \\
\text { pleased] }\end{array}$ & & & 0.930 \\
\hline SAT3 & c. $[$ Semantic differential scale from $1=$ frustrated to $7=$ Contented] & & & 0.925 \\
\hline SAT4 & d. [Semantic differential scale from $1=$ disappointed to $7=$ Delighted] & & & 0.922 \\
\hline \multicolumn{2}{|c|}{ Intention to Continue to Use } & 0.940 & 0.797 & \\
\hline IUSE1 & I intend to continue using the Blackboard rather than discontinue its use & & & 0.872 \\
\hline IUSE2 & $\begin{array}{l}\text { My intentions are to continue using the Blackboard than use any alternative } \\
\text { technology }\end{array}$ & & & 0.858 \\
\hline IUSE3 & If I could, I would like to continue my use of Blackboard & & & 0.924 \\
\hline IUSE4 & I will continue to use the Blackboard in the future & & & 0.915 \\
\hline
\end{tabular}

\subsection{Model Testing and Hypothesis Testing}

Figure 2 depicts estimated path coefficients, associated t-value of the paths, as well as the variance explained of the research model. The model explains 41.2 percent of the variance in intention to continue to use, 79.2 percent of the variance in overall satisfaction, 40.1 percent and 42.9 percent in information satisfaction and system satisfaction respectively.

A bootstrap resampling method was used to test the significance of path estimates. As shown in Figure 2, all path coefficients are found to be statistically 


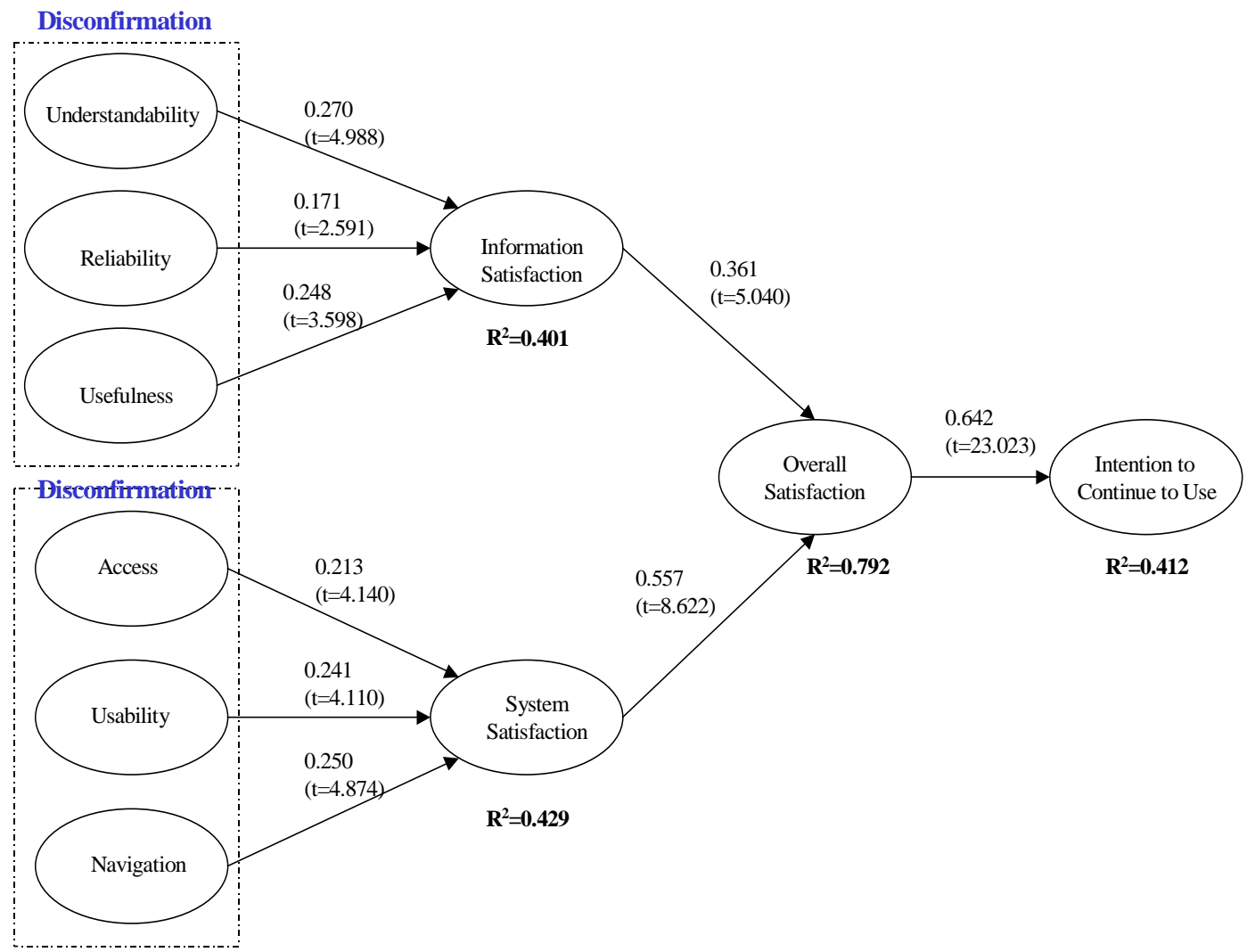

Figure 2. Result of the research model

significant as hypothesized. Overall satisfaction has a significant strong impact on intention to continue to satisfaction $(\beta=0.361, \quad t=5.040)$ and system satisfaction $(\beta=0.557, \mathrm{t}=8.622)$. The results provided empirical support to $\mathrm{H} 1, \mathrm{H} 2$, and $\mathrm{H} 3$. Disconfirmation in understandability, usefulness, and reliability exhibit a moderate impact on information satisfaction with path coefficient at $0.270,0.248$, and 0.171 respectively. The results provide empirical

\section{Conclusion and Discussions}

The purpose of this study is to identify important antecedents and consequences of user satisfaction with e-learning portals. The web-customer satisfaction model [15] was extended by including the construct of intention to continue to use. This model was theoretically supported by expectationdisconfirmation theory and was empirical evaluated by 504 students in a local university. Empirical findings demonstrated that our research model provided a relatively high explanatory power. Moreover, all associated hypotheses were found to be statistically significant. The implications of this study are noteworthy for both researchers and practitioners. use ( $\beta=0.642$, $t=23.023$ ), whilst overall satisfaction is significantly affected by information supports to $\mathrm{H} 4, \mathrm{H} 5$, and H6. Disconfirmation in navigation, usability, and access also posit a moderate impact on system satisfaction with path coefficient at $0.250,0.241$, and 0.213 respectively. The results provide empirical supports to H7, H8, and H9.

\subsection{Research Implications}

The research model helps explain three basic issues (1) what defines user satisfaction with an elearning portal, (2) how user satisfaction is formed, and (3) which attributes are relatively important to the formation of user satisfaction. Specifically, this study contributes to both IT usage and e-learning research by identifying antecedents and consequences of user satisfaction with e-learning portals. The high explanatory power of our research model provides researchers new insights that satisfaction should be speculated on in terms of information satisfaction and system satisfaction in the context of web-based application.

This study also highlights the importance of satisfaction as a primary driver for intention to continue to use. Moreover, the expectation 
disconfirmation theory integrates quite well with the McKinney et al. [15] model and provides significant explanation of user satisfaction with an e-learning portal.

\subsection{Practical Implications}

While this study leads to several interesting implications for research, it also provides important insights on the design and implementation of elearning portals to educators and academic institutions. According to the results of this study, overall satisfaction exhibits a significant strong impact on the intention to continue to use an elearning portal, institutions or instructors should try to maintain student satisfaction with the use of the portal in order to have them continue to use it. In addition, system satisfaction posits a higher effect on overall satisfaction. System designers should pay attention to the hygienic factors and should create an accessible, usable, and an easily-navigable e-learning portal during the design process.

\subsection{Limitations and Future Research}

In interpreting the results of this research, one must pay attention to a number of limitations. First, the main purpose of this study is to examine the antecedents and consequences of user satisfaction with an e-learning portal. In the IS literature, a number of researchers have already argued that it is important to consider the concept of habit in the study of IS continuance [26]. Future studies should continue to explore the impacts of both user satisfaction and habit on IS continuance. Second, the dimensions of information quality and system quality are directly borrowed from McKinney et al. [15]. Future research should identify few more dimensions that are specific to the e-learning environment. Finally, the data was collected from a convenience sample in a university in Hong Kong, therefore, generalization of the findings to other sample populations or other types of e-learning portals should be made with caution.

\section{References}

[1] M.K.O. Lee, C.M.K. Cheung, and Z. Chen, "Acceptance of Internet-based Learning Medium: The Role of Extrinsic and Intrinsic Motivation”, Information \& Management 42 (8), 2005, pp. 1095-1104.

[2] G. Piccoli, R. Ahmad, and B. Ives, "Web-based Virtual Learning Environments: A Research Framework and a Preliminary Assessment of Effectiveness in Basic IT Skills Training”, MIS Quarterly 25 (4), 2001.

[3] C.S. Ong, J.Y. Lai, and Y.S. Wang, "Factors Affecting Engineers' Acceptance of Asynchronous e-Learning
Systems in High-tech Companies”, Information \& Management 41(6), 2004, pp. 795-804.

[4] M. Limayem and C.M.K. Cheung, "Understanding Information Systems Continuance: The Case of InternetBased Learning Technologies”, Information \& Management 45 (4), 2008, pp. 227-232.

[5] Riva, G. (2001) "From Real to Virtual Communities: Cognition, Knowledge, and Intention in the World Wide Web", C.R. Wolfe, Learning and Teaching on the World Wide Web, Academic Press: San Diego, California, ch. 7 p. 131-151.

[6] C.M.K. Cheung and M.K.O. Lee, "User Satisfaction with an Internet-Based Portal: An Asymmetric and Nonlinear Approach", Journal of the American Society for Information Science and Technology 60 (1), 2009, pp. 111122.

[7] W.H. DeLone and E.R. McLean, "The DeLone and McLean Model of Information Systems Success: A TenYear Update", Journal of Management Information Systems 19, 2003, pp. 9-30.

[8] N.P. Melone, "A Theoretical Assessment of the UserSatisfaction Construct in Information Systems Research", Management Science 36 (1), 1990, pp. 76-91.

[9] Oliver, R.L. (1997) Satisfaction: A Behavioral Perspective on the Consumer, McGraw-Hill, New York.

[10] A. Bhattacherjee, "Understanding Information Systems Continuance: An Expectation Confirmation Model", MIS Quarterly 25 (3), 2001, pp. 351-370.

[11] W.J. Doll and G. Torkzadeh, "A Discrepancy Model of End-user Computing Involvement", Management Science 35 (10), 1989, pp. 1151-1170.

[12] W.H. DeLone and E.R. McLean, "Information system success: the quest for the dependent variable", Information Systems Research 3 (1), 1992, pp. 60-95.

[13] R. Arun, S.S. Lang, and R.B. Welker, "Assessing the Validity of IS Success Models: An Empirical Test and Theoretical Analysis", Information Systems Research 13 (1), 2002, pp. 50-69.

[14] D. Sarv, M. Fan, and R. Kohli, "Antecedents of B2C Channel Satisfaction and Preference: Validating eCommerce Metrics," Information Systems Research 13 (3), 2002, pp. 316-333.

[15] V. McKinney, K. Yoon and M. Zahedi, "The Measurement of Web-Customer Satisfaction: An Expectation and Disconfirmation Approach", Information Systems Research, 13 (3), 2002, pp. 296-315.

[16] J.P. Shim, Y.B. Shin, and L. Nottingham, "Retailer Web Site Influence on Customer Shopping," Journal of the Association for Information Systems (3) 3, 2002, pp. 53-76.

[17] H.Y. Lin, P.Y. Hsu, and P.H. Ting, "ERP Systems Success: An Integration of IS Success Model and Balanced 
Scorecard," Journal of Research and Practice in Information Technology (38) 3, 2006, pp. 215-228.

[18] X. Jin, C.M.K. Cheung, M.K.O. Lee, and H.P. Chen, "How to Keep Members Using the Information in a Computer-Supported Social Network", Computers in Human Behavior 25 (5), 2009, pp. 1172-1181.

[19] R.L. Oliver, "A Cognitive Model of the Antecedents and Consequence of Satisfaction Decisions", Journal of Marketing Research 17, 1980, pp. 460-469.

[20] F.D. Davis, "Perceived Usefulness, Perceived Ease of Use, and User Acceptance of Information Technology", MIS Quarterly 13, 1989, pp. 319-339.

[21] J. Alba, J. Lynch, B. Weitz, C. Janiszewski, R. Lutz, A. Sawyer, and S. Wood, "Interactive Home Shopping: Consumer, Retailer, and Manufacturer Incentives to Participatein Electronic Markets," Journal of Marketing 61 (3), 1997, pp. 38-53.

[22] S.L. Jarvenpaa and P.A. Todd, "Consumer Reactions to Electronic Shopping on the World Wide Web," Journal of Electronic Commerce 1 (2), 1997, pp. 59-88.

[23] Hair, J.F., Anderson, R.E., Tatham, R.L. and, Black, W.C. (1998) Multivariate Data Analysis, Prentice-Hall, Englewood Cliffs, NJ.

[24] Chin, W.W. (1998) "The Partial Least Squares Approach for Structural Equation Modeling", G.A. Marcoulides, Modern Methods for Business Research, Lawrence Erlbaum Associates: Hillsdale, NJ, p. 295-336.

[25] C. Fornell, and D.F. Larcker, "Evaluating Structural Equation Models with Unobservable Variables and Measurement Error," Journal of Marketing Research 18, 1981, pp. 39-50.

[26] M. Limayem, S.G. Hirt, and C.M.K. Cheung, "How Habit Limits the Predictive Power of Intentions: The Case of IS Continuance”, MIS Quarterly 36 (4), 2007, pp. 705737. 